\title{
PENGARUH PSYCHODRAMA DALAM MENURUNKAN KECENDERUNGAN DEPRESI PADA REMAJA DI PANTI ASUHAN
}

\author{
Ulfie Zaidatul Aulia dan Ratna Supradewi \\ Fakultas Psikologi Universitas Islam Sultan Agung, Jl. Kaligawe Raya, No.4, Kota Semarang, 50112 \\ Email: ulfieau@std.unissula.ac.id, supradewi@unissula.ac.id
}

\begin{abstract}
Abstrak
Penelitian ini bertujuan untuk mengetahui pengaruh psychodrama dalam menurunkan kecenderungan depresi pada remaja di panti asuhan. Desain pada penelitian ini adalah pre-test post-test control group design. Populasi pada penelitian ini adalah remaja di Panti Asuhan Ar-Rodiyah Semarang. Teknik pengambilan sampel yang digunakan adalah purposive sampling dengan sampel berjumlah 5 orang pada kelompok eksperimen dan 5 orang pada kelompok kontrol. Psychodrama diberikan sebanyak 2 sesi dengan jeda waktu 13 hari dari sesi pertama hingga sesi kedua. Psychodrama dilakukan dengan menggunakan modul yang telah dimodifikasi dan disesuaikan dengan penelitian yang dilakukan serta telah mendapat penilaian kelayakan dari Psikolog. Skala yang digunakan pada penelitian ini adalah skala kecenderungan depresi yang terdiri dari 34 aitem dengan koefisien reliabilitas cronbach's alpha sebesar 0,914. Teknik analisis data yang digunakan pada penelitian ini adalah paired sample t-test dan independent sample t-test. Hasil uji hipotesis pertama menunjukkan nilai taraf signifikansi (1-tailed) sebesar 0, $115>0,05$, yang artinya tidak ada perbedaan pada kelompok eksperimen antara sebelum dengan sesudah diberi perlakuan psychodrama. Hal tersebut menunjukkan bahwa tidak ada pengaruh psychodrama pada kelompok eksperimen dalam menurunkan kecenderungan depresi. Hasil uji hipotesis kedua menunjukkan nilai taraf signifikansi (1-tailed) sebesar 0,004<0,05, yang artinya ada perbedaan skor post-test pada kelompok eksperimen dengan kelompok kontrol. Hal tersebut menunjukkan bahwa ada pengaruh psychodrama pada kelompok eksperimen dibuktikan dengan adanya perbedaan yang signifikan pada hasil post-test antara kelompok eksperimen dengan kelompok kontrol.
\end{abstract}

Kata kunci: kecenderungan depresi, psychodrama

\section{THE EFFECT OF PSYCHODRAMA IN REDUCING DEPRESSION TENDENCY AMONG ADOLESCENTS IN ORPHANAGES}

\begin{abstract}
This study aimed to determine the effect of psychodrama in reducing depression tendency in adolescents in orphanages. The design in this study was a pre-test post-test control group design. The population in this study were adolescents at the Ar-Rodiyah Orphanage Semarang. This tudy used purposive sampling methods with a sample of 5 people in the experimental group and 5 people in the control group. Psychodrama was given in 2 sessions with a time interval about 13 days between the first sessions and the second one. Psychodrama is carried out using modules that have been modified and adapted to the research being carried out and have received a feasibillity assesment from a Psychologist. The scale used in this study was a depression tendency scale consisting of 34 items with a cronbach's alpha reliability coefficient of 0,914. The data analysis in this study used paired sample t-test and independent sample t-test. The result of the first hypothesis test showed a significance level value (1-tailed) of $0,115>0,05$, which means that there was no difference in the experimental group between before and after being given psychodrama treatment. This show that there is no effect of psychodrama in the experimental group in reducing depression tendencies. The results of the second hypothesis test showed a significance level value (1-tailed) of 0,004<0,05, which means that there was a difference in post-test scores in the experimental group with the control group. This show that there is an effect of psychodrama in the experimental group as evidenced by a significant difference in the post-test result between the experimental group and the control group
\end{abstract}


Keyword: depression tendency, psychodrama

\section{Pendahuluan}

Kehidupan yang dijalani anak atau remaja di panti asuhan memiliki beberapa tantangan, diantaranya adalah jumlah pengurus panti yang sedikit dapat berakibat pada anak asuh dalam mendapatkan perhatian dan kasih sayang dimana pada masa-masa tersebut kasih sayang serta perhatian orang tua begitu diperlukan (Illahi \& Akmal, 2018). Kondisi ini dapat menyebabkan anak atau remaja kurang mendapatkan bimbingan yang intensif dari pengurus atau pengasuh. Sikap teman- teman di panti juga terkadang menimbulkan perkelahian sehingga anak atau remaja di panti asuhan menarik diri untuk berinteraksi di lingkungan sosial. Hal tersebut juga dapat berpengaruh pada sosial anak di sekolah, baik dengan teman ataupun guru, bahkan bisa berpengaruh pada pencapaian akademik anak (Rahmawati, Listiyandini, \& Rahmatika, 2019).

Data Badan Pusat Statistik menyebutkan bahwa menurut Dinas Sosial Provinsi Jawa Tengah pada 2015 ada 4 panti asuhan milik pemerintah dan sebanyak 86 panti asuhan milik swasta, sehingga total panti asuhan yang ada di Provinsi Jawa Tengah adalah 90. Jumlah anak asuh pada panti asuhan milik pemerintah sebanyak 435 dan anak asuh pada panti asuhan milik swasta sebanyak 3.608, sehingga total anak asuh yang tinggal di panti asuhan Provinsi Jawa Tengah sebanyak 4.048 anak (Statistik, 2018).

Jahja (dalam Putro, 2017) mengemukakan bahwa masa remaja ialah masa storm and stress, yaitu masa dimana remaja mengalami peningkatan emosional yang disebabkan oleh hormon serta perubahan fisik pada masa ini. Tuntutan tugas baik tugas akademik hingga tugas di lingkungan sosial serta tuntutan akan kemandirian dan tanggung jawab pada masa remaja sangat memengaruhi emosional individu. Apabila tuntutan akan tugas, kemandirian, dan tanggung jawab tidak dapat diselesaikan dengan baik maka akan dapat menyebabkan stress hingga depresi.

Sesuai paparan Atkinson (1991), depresi adalah salah satu gangguan mood dimana bercirikan pada individu yang tidak memiliki harapan serta patah hati, tidak berdaya yang berlebih, tidak bisa melakukan pengambilan keputusan dengan baik, tidak bisa konsentrasi, enggan untuk melakukan kegiatan, tidak memiliki semangat hidup, terus bersikap tegang, serta mencoba bunuh diri atau mengakhiri hidup. Depresi ialah gangguan perasaan (afektif) dimana gejalanya berkaitan akan aspek disforik (kehilangan kegembiraan atau gairah), serta berbagai gejala lainnya misal gangguan makan serta gangguan tidur(Lubis, 2009).

Depresi dapat diklasifikasian dan diukur dalam berbagai tingkatan, diantaranya adalah gejala suasana hati sedih, sindrom (gejala terkait secara teoritis atau empiris), atau gangguan klinis (sekumpulan gejala yang memenuhi kriteria diagnostik tertentu). Depresi tidak lagi dipandang sebagai cerminan badai dan stress normatif melainkan gangguan yang merusak dan berulang yang berpotensi merusak kesejahteraan hingga dewasa. Penelitian epidemiologi mengungkapkan secara konsisten bahwa depresi pada remaja mengalami penigkatan yang nyata. Usia remaja pertengahan hingga akhir terdapat diagnosis depresi sebanding dengan diagnosis yang ditemukan pada orang dewasa. Penelitian prospektif mengungkapkan puncak onset depresi pada remaja terjadi pada masa pertengahan remaja, sekitar 13-15 tahun (Gotlib \& Hammen, 2009). 
Gejala depresi menurut Ghani (2013) yaitu timbulnya perasaan sedih dalam jangka waktu yang lama, lebih sering menyendiri, nafsu makan menurun atau bertambah, sering melamun, merasa kurang bertenaga, merasa lesu dan letih, sulit untuk tidur atau tidur berlebihan, sulit untuk mengambil keputusan, merasa rendah diri dan putus asa. Selain itu terdapat beberapa gangguan yang muncul akibat adanya depresi. Beberapa gangguan tersebut diantaranya adalah gangguan yang bersifat interpersonal, intrapersonal, gangguan dalam melakukan pekerjaan, pola makan, pola tidur, serta gangguan tingkah laku maladaptif yang berupa penyalahgunaan narkoba, alkohol, merokok sebagai cara agar individu merasa lebih baik. Dampak yang paling buruk dari depresi adalah timbulnya keinginan untuk bunuh diri karena merasa hidupnya tidak berguna (Desi \& Setiawan, 2018).

Studi epidemiologi menemukan bahwa prevalensi depresi lebih tinggi pada remaja yatim piatu. Salah satu penelitian oleh Ibrahim dkk. terkait prevalensi dan predisposisi depresi remaja yatim piatu di Mesir menghasilkan jika ada $20 \%$ remaja yatim piatu mengalami depresi. Bukan saja kondisi tersebut, depresi umumnya banyak dialami oleh remaja yatim piatu berjenis kelamin perempuan daripada laki-laki. Penelitian lainnya oleh Bhat di Kashmir di bagian utara India, memaparkan jika remaja yatim piatu mempunyai taraf emosi cenderung stabil dan memiliki tingkat depresi yang lebih berat daripada remaja bukan yatim piatu (Wetarini \& Lesmana, 2018). Berdasarkan penelitian sebelumnya yang dilakukan oleh (Wetarini \& Lesmana, 2018) di Denpasar dapat diketahui bahwa remaja yang tinggal di panti asuhan rentan mengalami depesi. Oleh karena itu, diperlukan bimbingan konseling dan pelayanan sosial yang baik untuk mengatasi masalah tersebut. Penelitian yang dilakukan oleh Bhat (2014) di India menemukan bahwa remaja yang tinggal di panti asuhan yatim piatu memiliki tingkat emosi yang lebih stabil serta tingkat depresi yang lebih berat dibanding dengan remaja yang tidak tinggal di panti asuhan.

Penelitian epidemiologi mengungkapkan secara konsisten bahwa depresi pada remaja mengalami penigkatan yang nyata. Usia remaja pertengahan hingga akhir terdapat diagnosis depresi sebanding dengan diagnosis yang ditemukan pada orang dewasa. Penelitian prospektif mengungkapkan puncak onset depresi pada remaja terjadi pada masa pertengahan remaja, sekitar 13-15 tahun (Gotlib \& Hammen, 2009). Depresi pada remaja di panti asuhan dapat disebabkan oleh berbagai hal. Tugas dan tuntutan yang dihadapi remaja baik di sekolah ataupun di panti dapat memicu stres yang berlebih kemudian dapat menyebabkan mengalami kecenderungan depresi. Jika hal tersebut tidak diatasi maka akan berdampak pada psikologis remaja dalam perkembangan kehidupannya menuju masa depan.

Definisi psikodrama adalah suatu cara mempraktekkan hidup tanpa perlu memperhatikan penghakiman orang-orang atas kesalahan-kesalahan yang dilakukan. Peran-peran yang dimainkan adalah cara untuk melihat kehidupan nyata bagaimana adanya. Psikodrama adalah cara untuk mengekspresikan apa yang sudah terjadi dan apa yang belum terjadi dalam hidup dan setiap anggota dari kelompok suatu psikodrama merupakan agen-agen terapeutik bagi sesamanya(Karp \& Bradshaw, 1998). Penggunaan psikodrama dalam menurunkan kecenderungan depresi adalah remaja di panti yang mengalami kecenderungan depresi akan diberikan psikodrama yang berupa sebuah drama yang dimainkan oleh remaja-remaja tersebut dan terdapat berbagai peran. Di panggung psikodrama bebas untuk mengekspresikan dan mengungkapkan apapun yang mungkin di kehidupan nyata tertahan dan tidak dapat di keluarkan. Peran-peran yang dimainkan merupakan gambaran yang mewakili komponen-komponen di kehidupan nyata protagonist. Peran pembantu pun dapat merasakan sebagai refleksi diri serta membantu protagonis untuk mengungkapkan 
perasaan dan tindakan yang tertahan. Seringkali perasaan dan tindakan yang tertahan di kehidupan nyata hanya bisa dipendam oleh seseorang, sehingga hal tersebut dapat menjadi tekanan batin dan memicu terjadinya kecenderungan depresi apabila tidak diatasi dengan baik. Penggunaan psikodrama juga dapat menjadi suatu proses pendewasaan pada seseorang, dimana hal tersebut akan membantu untuk menentukan keputusan di masa depan.

Ciri khas dari desain psikodrama adalah segalanya sesuatu dimulai dan selesai pada waktu dan ruang yang telah disediakan. Subjek diizinkan untuk membuat adegan-adegan detail pada kehidupan nyata, boleh menekankan suatu momen atau situasi penting dalam hidupnya tanpa memikirkan hal tersebut monoton atau tidak. Hal tersebut dapat membuat subjek lega karena berhasil menjalani hidupnya sesuai dengan keinginannya. Terapi peran atau psikodrama bukan subuah pengadilan, peran pembantu yang mungkin hadir bukan sebagai juri, sutradara atau direktor bukan sebagai hakim. Kemudian panggung psikodrama bukanlah rumah sakit dimana subjek rela berkorban untuk menunjukkan luka atau penyakit yang ia derita dan berharap agar dapat disembuhkan oleh profesional, dima yang dimaksud profesional adalah ketika sutradara berganti peran menjadi terapis jika dalam konteks terapi. Spontanitas tindakan, inisiatif, serta keputusan harus berasal dari subjek itu sendiri (Moreno, 1987).

Menurut (Blatner, 1996) selain komponen utama, dalam psikodrama terdapat berbagai macam variasi teknik yang dapat digunakan. Teknik-teknik tersebut meliputi double (ganda), teknik ini dapat diambil oleh peran bantu protagonis. Peran pembantu dalam protagonis bertugas untuk membantu protagonis untuk mengekspresikan perasaan batin dengan jelas. Teknik soliloquy atau self talk (berbicara sendiri), teknik ini meliputi peran protagonis untuk berbicara sendiri mengenai situasinya. Teknik mirroring (bercermin) yaitu protagonis melihat dirinya sendiri dari luar panggung, peran pembantu memantulkan kata-kata dan gerakan apakah adegan tersebut sesuai dengan keinginan protagonis. Hal ini dapat menjadi refleksi untuk mengenal lebih diri sendiri pada protagonis. Teknik creative imagery (imajinasi) yaitu membayangkan dan merasakan suatu peristiwa, teknik ini biasa digunakan pada tahap warming-up (pemanasan). Teknik sclupture (memahat) yaitu membuat pose kemudian mematung, pada teknik ini anggota kelompok psikodrama akan diajak untuk merasakan makna dari pose tersebut.

Teknik monodrama dalam terapi gestalt merupakan hal inti. Teknik tersebut dapat digunakan apabila protagonis dalam posisi terapi individu. Kemudian ketika direktur ingin mengetahui jawaban yang ingin ditemukan dari protagonis berasal dari dalam dirinya sendiri. Selain itu apabila protagonis dapat memainkan dua peran sekaligus tanpa peran pembantu. Teknik role reversal (pertukaran peran) yaitu menggunakan media kursi kosong, teknik ini merupakan metode terapi gestalt oleh Frederick Perls. Kursi kosong tersebut dapat mewakilkan sesuatu, misalnya digunakan untuk objek kemarahan protagonis yang tidak dapat ia luapkan dalam kehidupan nyata ataupun digunakan sebagai proses perpindahan ke dan dari. Selain itu dapat digunakan sebagai objek yang mewakili seseorang, dimana protagonis akan mengatakan sesuatu yang mungkin di kehidupan nyata tidak tersampaikan. Penggunaan kursi tersebut dapat digunakan untuk pertukaran peran protagonis kepada peran pembantu. Teknik de-rolling yaitu pembalikan peran, teknik tersebut merupakan sebuah proses pelepasan peran yang telah dilakukan dalam proses psikodrama agar protagonis dan peran pembantu kembali pada perannya masing-masing pada realita kehidupan (Blatner, 1996).

44 
Teknik lain dalam psikodrama adalah sosiometri, dikembangkan oleh Moreno untuk membangun hubungan sosial. Dalam setting psikodrama kelompok maka digunakan dalam kelompok. Terdapat dua teknik yaitu lokogram dan spektogram. Teknik ini biasa digunakan pada tahap warming- up untuk mengetahui sejauh mana keinginan keterlibatan pada masing-masing anggota kelompok (Moreno, 1987).

Penelitian sebelumnya yang dilakukan oleh Vera Yulandasari pada tahun 2019 di Panti Sosial Tresna Werdha Mataram, menemukan bahwa penggunaan Terapi Aktivitas Kelompok (TAK) Psikodrama mampu memotivasi responden untuk menggali emosional pada masa lalu sebagai sumber depresi sebagai peran yang tampilkan (Yulandasari, 2019). Perbedaan dengan penelitian sebelumnya terletak pada subjek, tempat dan teknik analisis data yang digunakan.

Hipotesis pada penelitian ini adalah ada penurunan kecenderungan depresi pada kelompok eksperimen antara sebelum dengan sesudah diberi perlakuan psychodrama dan ada perbedaan kecenderungan depresi antara kelompok eksperimen dan kelompok kontrol. Tujuan dari penelitian ini adalah untuk mengetahui adanya penurunan tingkat kecenderungan depresi pada remaja di Panti Asuhan setelah menggunakan terapi psikodrama dibanding dengan sebelum menggunakan terapi psikodrama.

\section{Metode Penelitian}

Penelitian ini diawali dengan melakukan screening pada remaja di panti asuhan Ar-Rodiyah Semarang. Screening dilakukan untuk memilih kelompok eksperimen dengan kriteria subjek berusia 12-17 tahun. Screening ini dilakukan menggunakan skala kecenderungan depresi dari Oei Florencia Astari Wijaya pada tahun 2019 dengan reliabilitas sebesar $\alpha=0,914$. Skala tersebut terdiri dari 34 aitem yang meliputi simtom manifestasi emosional, simtom manifestasi kognitif, simtom manifestasi motivasional serta simtom manifestasi vegetatif dan fisik. Modul psychodrama dimodifikasi dari Archangela Girlani tahun 2019 kemudian disesuaikan dengan penelitian yang diteliti.

Teknik pengambilan sampel yang digunakan pada penelitian ini adalah purposive sampling. Kriteria subjek penelitian adalah remaja panti asuhan dengan kecenderungan depresi yang berusia 1-17 tahun. Teknik ini dilakukan dengan cara mengundi subjek yang sesuai kriteria untuk dibagi ke dalam kelompok eksperimen dan kelompok kontrol dengan cara ABBA untuk menyetarakan mean antara kelompok eksperimen dengan kelompok kontrol. Kemudian diperoleh 5 subjek untuk kelompok eksperimen dan 5 subjek untuk kelompok kontrol. Data yang didapatkan pada proses screening juga digunakan untuk data pre-test.

Metode yang dipilih adalah eksperimen dengan rancangan pretest- posttest with control group design. Kelompok eksperimen dan kontrol diberikan pretest menggunakan skala kecenderungan depresi. Kemudian kelompok eksperimen diberikan perlakuan psychodrama sebanyak 2 kali dengan jeda waktu 13 hari dari pertemuan pertama ke pertemuan kedua. Setelah itu kelompok eksperimen diberikan posttest, kelompok kontrol juga diberikan posttest tanpa diberi perlakuan.

Teknik analisis data yang digunakan adalah Paired Sample T-Test dan Independet Sample TTest. Kemudian alat pengumpulan data menggunakan wawancara pendahuluan, lembar observasi, lembar evaluasi, dan self monitoring. Selain itu dilakukan juga wawancara dengan pengasuh panti asuhan. 
Tabel 1. Indeks Validitas dan Reliabilitas Alat Ukur

\begin{tabular}{lccc}
\hline Alat Ukur & Jumlah Aitem Valid & Indeks Daya Beda Aitem & Koefisien Reliabilitas \\
\hline Kecenderungan Depresi & 34 & $0,301-0,608$ & 0,914
\end{tabular}

\section{Hasil Penelitian}

Penelitian diawali dengan melakukan screening dan pretest pada remaja di panti asuhan. Sebelum melakukan uji hipotesis, peneliti melakukan uji normalitas dan uji homogenitas terlebih dahulu. Uji normalitas menggunakan One Sample Kolmogorov-Smirnov Test dengan taraf signifikansi lebih dari 0,05 yang berarti bahwa data berdistribusi normal. Analisis menggunakan SPSS versi 22.

Tabel 2. Hasil Analisis Uji Normalitas

\begin{tabular}{cccc}
\hline Skala & Sig. & $\mathbf{p}$ & Keterangan \\
\hline Pre-test eksperimen & 0,307 & $>0,05$ & Normal \\
Pre-test kontrol & 0,256 & $>0,05$ & Normal \\
\hline
\end{tabular}

Hasil uji normalitas yang diperoleh dari data pre-test kelompok eksperimen dengan taraf signifikansi $0,307(p>0,05)$ dan kelompok kontrol memiliki taraf signifikasi 0,256 ( $p>0,05)$, maka dapat disimpulkan bahwa skala pre-test berdistribusi normal. Tahap selanjutnya peneliti melakukan uji homogenitas untuk mengetahui apakah data homogen atau tidak. Hasil uji homogenitas yang diperoleh menunjukkan nilai levene pada skor pre-test adalah 0,083 dengan taraf signifikansi 0,396 $(p>0,05)$ maka menunjukkan bahwa data tersebut homogen.

Tabel 3. Hasil Analisis Uji Homogenitas

\begin{tabular}{cccc}
\hline Levene & Sig. & $\mathbf{p}$ & Keterangan \\
\hline 0,803 & 0,396 & $>0,05$ & Homogen \\
\hline
\end{tabular}

Berdasarkan uji hipotesis yang telah dilakukan menggunakan analisis data uji Paired Sample $T$ - Test, dimana peneliti ingin mengetahui perbedaan yang bermakna antara hasil pre-test dan post test pada kelompok eksperimen. Taraf signifikansi pada uji statistik penelitian ini menggunakan uji hipotesis satu arah (1-tailed). Pada data pre-test dan post-test kelompok eksperimen didapatkan taraf signifikansi (2-tailed) sebesar 0,231 >0,05 sehingga 0,231/2 (sig. 0,115) > 0,05 maka menunjukkan bahwa tidak ada perbedaan kecenderungan depresi pada kelompok eksperimen antara sebelum diberi perlakuan dengan sesudah diberi perlakuan. Mean pre-test kelompok eksperimen sebesar 33,60 dan mean post-test sebesar 23,40.

Tabel 4. Hasil Uji Hipotesis dengan Paired Sample T-test

\begin{tabular}{ccccc}
\hline Skala & Sig. (1-tailed) & $\mathbf{p}$ & $\mathbf{t}$ & Keterangan \\
\hline $\begin{array}{c}\text { Pretest- } \\
\text { posttest } \\
\text { eksperimen }\end{array}$ & 0,115 & $>0,05$ & 1,410 & $\begin{array}{c}\text { Tidak ada perbedaan yang } \\
\text { signifikan }\end{array}$ \\
\hline
\end{tabular}

Data post-test antara kelompok eksperimen dan kelompok kontrol didapatkan dianalisis menggunakan Independent Sample T-Test dengan taraf signifikansi (2-tailed) sebesar 0,008 < 0,05 sehingga 0,008/2 (sig. 0,004) <0,05 maka menunjukkan bahwa ada perbedaan kecenderungan depresi pada post-test kelompok eksperimen dengan kelompok kontrol. 
Tabel 5. Hasil Uji Hipotesis dengan Independent Sample T-Test

\begin{tabular}{cccccc}
\hline Skala & Sig. (1-tailed) & p & F & t & Keterangan \\
\hline $\begin{array}{c}\text { Posttest } \\
\text { Eksperimen } \\
\text { - Kontrol }\end{array}$ & 0,004 & $<0,05$ & 10,496 & $-3,514$ & $\begin{array}{c}\text { Ada perbedaan } \\
\text { yang signifikan }\end{array}$ \\
\hline
\end{tabular}

\section{Pembahasan}

Hasil penelitian ini tidak terbukti secara signifikan bahwa psikodrama dapat menurunkan kecenderungan depresi pada remaja di panti asuhan namun ada perbedaan yang signifikan dari hasil post-test antara kelompok eksperimen dengan kelompok kontrol. Penurunan mean juga terjadi pada kelompok eksperimen antara sebelum diberi perlakuan psikodrama dibanding dengan sesudah diberi perlakuan psikodrama. Kemudian jika dilihat dari data pretest-posttest kelompok eksperimen masing- masing subjek didapatkan bahwa terdapat 2 subjek mengalami penurunan 1 skor , 1 subjek memiliki skor yang tetap, 1 subjek mengalami penurunan 11 skor, dan 1 subjek mengalami penurunan 38 skor. Hal tersebut menandakan bahwa dinamika di dalam kelompok tersebut bervariasi. Penelitian ini tidak terbukti bahwa psychodrama mampu menurunkan kecenderungan depresi pada remaja di panti asuhan. Hal ini dapat disebabkan oleh beberapa faktor, salah satunya adalah pemahaman dan proses berpikir pada masing-masing individu terhadap proses psikodrama yang telah dilakukan sehingga tidak berhasil mendapatkan insight setelah proses selesai.

Hasil dari analisis Paired Sample T-Test pada uji perbedaan pre-post kelompok eksperimen dengan taraf signifikansi (1-tailed) sebesar 0,115 > 0,05 maka dapat disimpulkan bahwa tidak ada perbedaan yang signifikan, namun jika dilihat dari hasil mean terjadi perbedaan yaitu pada data pretest mean yang didapat sebesar 33,60 kemudian diberikan perlakuan sehingga pada post-test mean yang didapat sebesar 23,40 . Kemudian untuk melihat perbedaan antara post-test kelompok eksperimen dengan kelompok kontrol digunakan analisis Independent Sample T-test dengan taraf signifikansi (1-tailed) sebesar 0,004 $<0,05$. Hal ini menandakan bahwa ada pengaruh psikodrama pada kelompok eksperimen dibuktikan dengan adanya perbedaan yang signifikan pada hasil posttest antara kelompok eksperimen dengan kelompok kontrol. Kemudian untuk melihat perbedaan pada kelompok kontrol antara pre-test dengan post-test peneliti juga menggunakan analisis Paired Sample T-Test dengan taraf signifikansi (1-tailed) sebesar 0,04 0,05 maka dapat disimpulkan bahwa ada perbedaan yang signifikan, kemudian jika dilihat dari hasil mean terjadi perbedaan yaitu pada data pre-test mean yang dihasilkan sebesar 33,40 dan pada data post-test mean yang dihasilkan sebesar 43,80 .

Berdasarkan penelitian yang dilakukan oleh Walker tahun 2002 dengan 60 remaja dan hasil penelitian tersebut mengungkapkan bahwa ada beberapa penyebab utama dari permasalahan yang dialami remaja. Diantaranya adalah tekanan dari pihak sekolah oleh guru dengan diberikan banyaknya tugas dan pekerjaan rumah, adanya harapan dan tekanan yang berasal dari dalam diri maupun orang lain seperti orang harapan dari orang tua, adanya masalah ekonomi serta kejadian yang tidak diinginkan seperti perceraian orang tua, kematian, dan adanya penyakit yang dialami diri sendiri maupun orang-orang terdekatnya. Menurut Baldwin tahun 2002, faktor stress yang dialami remaja perempuan serta laki-laki secara umum tidak berbeda, namun dampaknya berbeda. Pada laki-laki biasanya lebih melampiaskan rasa stress dengan meminum alkohol ataupun merokok. 
Sedangkan perempuan biasanya lebih memiliki motivasi dan tuntutan yang tinggi yang berakibat mengalami beban psikis seperti sering merasa cemas, tidak merasa senang, sakit kepala dan sakit punggung (Desi \& Setiawan, 2018).

Psikodrama merupakan salah satu bentuk terapi kelompok disertai pula dengan konseling yang dapat digunakan untuk mengatasi kecenderungan depresi, dimana subjek atau anggota kelompok yang melakukan psikodrama didorong untuk memainkan suatu peran emosional secara spontan yang dilakukan tanpa latihan sebelumnya. Psikodrama bertujuan untuk membantu subjek mengatasi masalah-masalah pribadi melalui bermain peran, drama, dan tindakan (Casey, 2001). Melalui cara tersebut subjek dibantu untuk mengungkapkan perasaan-perasaan terpendam tentang konflik, kemarahan, kesedihan, kekecewaan, dan perasaan bersalah (Damanik, 2015). Setelah subjek mampu mengungkapkan perasaan-perasaan terpendamnya, kemudian subjek diharapkan mendapatkan insight (pemahaman baru) mengenai dirinya untuk digunakan di kehidupan nyata.

Hasil analisis kualitatif yang dilakukan dengan observasi, pemberian lembar self moitoring, dan pemberian lembar evaluasi individu menunjukkan bahwa masing-masing subjek merasakan kebermanfaatan dari psikodrama. Subjek kelompok eksperimen memberikan respon positif terhadap psikodrama ditinjau dari hasil lembar evaluasi individu masing-masing subjek. Hasil evaluasi individu dan pelatihan yang diberikan mendapatkan hasil rata-rata bahwa individu bisa lebih mampu menyadari kekurangan dan juga menjadi lebih berani untuk menjadi diri sendiri. Subjek juga mengungkapkan bahwa perasaannya menjadi lebih senang.

\section{Kesimpulan}

Kesimpulan pada penelitian ini adalah tidak ada perbedaan pada kelompok eksperimen antara sebelum dengan sesudah diberi perlakuan psychodrama, yang berarti bahwa psychodrama tidak berpengaruh dalam menurunkan kecenderungan depresi pada remaja di panti asuhan. Namun, pada hasil post-test antara kelompok eksperimen dan kelompok kontrol menunjukkan bahwa ada perbedaan antara kelompol eksperimen dengan kelompok kontrol. Jika dilihat dari mean antara kelompok eksperimen dengan kelompok kontrol didapatkan bahwa mean rata-rata kecenderungan depresi kelompok eksperimen menurun setelah diberi perlakuan psychodrama, sedangkan mean rata- rata kecenderungan depresi kelompok kontrol meningkat tanpa ada perlakuan apapun.

Saran untuk remaja di panti asuhan yaitu perlu disadari bahwa masing-masing individu memiliki potensi yang berbeda-beda. Jika memiliki permasalahan hendaknya mencari orang yang dirasa tepat untuk menjadi tempat bercerita. Perlu disadari pula bahwa tidak tinggal bersama dengan orang tua bukan berarti tidak mampu berbuat sesuatu tetapi mampu belajar mandiri dan mengontrol diri untuk mencapai cita-cita di masa depan.

Saran untuk peneliti selanjutnya adalah sebaiknya peneliti melakukan observasi yang mendalam untuk mengetahui terapi atau pelatihan yang sesuai dan memang dibutuhkan oleh subjek di tempat penelitian. 


\section{Daftar Pustaka}

Bhat, N. M. (2014). A study of emotional stability and depression in orphan secondary school students. International Journal of Education and Psychological Research (IJEPR), 3(2), 95-100.

Blatner, A. (1996). Acting-in practical applications of psychodramatic methods thir (J. Noulas, Ed.). New York: Springer Publishing Company.

Damanik, A. S. K. (2015). Psikodrama untuk menurunkan tingkat stres pada siswa akselerasi. Jurnal IImiah Psikologi Terapan, 3(2), 325-342.

Desi, S. F. B., \& Setiawan, H. (2018). Perbedaan gejala depresi pada remaja sekolah menengah pertama. Jurnal Universitas Kristen Satya Wacana Salatiga, 1(1), 1-9.

Gotlib, I. H., \& Hammen, C. L. (2009). Handbook of depression. In Psychiatric journal of the University of Ottawa : Revue de psychiatrie de I"Universite d"Ottawa (Vol. 14). https://doi.org/10.1007/978-3-642-73570-7_15

Karp, M., \& Bradshaw. (1998). The handbook of psychodrama. New York: Routledge.

Kurnia Illahi, S. P., \& Akmal, S. Z. (2018). Hubungan kelekatan dengan teman sebaya dan kecerdasan emosi pada remaja yang tinggal di panti asuhan. Psikohumaniora: Jurnal Penelitian Psikologi, 2(2), 171. https://doi.org/10.21580/pjpp.v2i2.1854

Lubis, N. L. (2009). Depresi Tinjauan Psikologi. Kencana.

Moreno, J. L. (1987). The essential moreno (J. Fox, Ed.). New York: Springer Publishing Company.

Putro, K. Z. (2017). Memahami ciri dan tugas perkembangan masa remaja. Jurnal Aplikasi IImu-IImu Agama, 17(1), 25-32. Retrieved from http://ejournal.uinsuka.ac.id/pusat/aplikasia/article/viewFile/1362/1180

Rahmawati, B. D., Listiyandini, R. A., \& Rahmatika, R. (2019). Resiliensi psikologis dan pengaruhnya terhadap kualitas hidup terkait kesehatan pada remaja di panti asuhan. Jurnal Magister Psikologi UMA, 11(1), 21-30.

Statistik, B. P. (2018). Banyaknya panti asuhan dan pengelola menurut kabupaten kota di jawa tengahtahun 2015. Retrieved from Google website: https://jateng.bps.go.id/statictable/2016/08/26/1388/banyaknyapanti-asuhan-dan-pengelola- menurut-kabupaten-kota-di-jawa-tengah-tahun-2015.html

Wetarini, K., \& Lesmana, C. B. J. (2018). Gambaran depresi dan faktor yang memengaruhi pada remaja yatim piatu di denpasar. E-Jurnal Medika, 7(2), 82-86.

Yulandasari, V. (2019). Efektivitas terapi aktivitas kelompok model interpersonal dan model psikodrama terhadap perubahan tingkat depresi lansia: studi kasus di panti sosial tresna werdha mataram. Jurnal Kesehatan Qamarul Huda, 7(1), 36-40 